\title{
THE TAXONOMY OF FORESTRY TERMS IN THE MODERN UKRAINIAN LANGUAGE
}

\author{
Oksana Hrydzhuk
}

\author{
Ukrainian National Forestry University, Lviv, Ukraine \\ oxana.hrydzhuk@gmail.com
}

\begin{abstract}
The subject of the research is the analysis of forestry vocabulary. The purpose is to promote the enhancement taxonomy of forestry vocabulary in the modern Ukrainian language. For the analysis of the forestry vocabulary, we used such methods as scientific sources investigation, a descriptive method, methods of comparison, analysis and synthesis, as well as methods of classification and systematisation. Forestry vocabulary provided in the article includes terms, professionalisms, terminologised common lexical units and nomenclature nominations. We have revealed that forestry terminology contains general scientific terms, interdisciplinary terms and specific forestry terms. Terminological lexical units are understandable to everyone, but these lexemes are the obligatory component of the forestry terminological system, without them its integrity will be broken. We suggest paying special attention to the use of professionalisms that is caused by the peculiarities of the specialists' activities and is associated with the use of a significant number of dialect names. Nomenclature names are used to designate as follows: wood species, types of cutting, means of the direct extinguishing of forest fires. Latin names of flora and fauna and taxonomic names are also considered to be the nomenclature names. The research has shown that these classes of nominative units (terms, professionalisms and dialect names) are applied simultaneously in forestry terminology. The need for proper knowledge of the terms and rules of their combination justifies the students' expediency to study the peculiarities of forestry vocabulary taxonomy. Mastering of terms will help students avoid mistakes in their speech, and improve the quality of future specialists' professional speech and also the level of terminological knowledge in general. The theoretical material developed is supposed to become the basis for practical classes and will be presented in future academic research in the didactic aspect.
\end{abstract}

Keywords: forestry terminology; general scientific terms; inter-disciplinary terms; specific terms; terminologised common lexical units; professionalisms; nomenclature nominations.

\section{Introduction}

In recent years, researchers have become increasingly interested in theoretical issues of professional terminology functioning, caused by some applied aspects. The increased need for the improving of students' professional speech, for the formation of the professional language skills and terminological knowledge of future forestry workers have stipulated the study of theoretical aspects of forestry terminology functioning and specificity of its system organisation.

The works of Ukrainian and foreign scholars on the theoretical foundations of terminology, in particular the analysis of terminology concerning its system organisation (Vynokur (1939), Kyiak (2007), Kochan (2004), Lotte (1961) et al.), the specifics of the use of nominative units (Pavlova (2008), Prystaiko (1996), Superanskaya, Podolskaya \& Vasyleva (2005)) are of paramount importance for our research. Since the level of scientific language development makes an influence on intellectual evolution of society and testifies the state of language self-disclosure of the nation (Doroshenko, Lysenko \& Tievikova (2018)), the study of professional terminology is urgent. The forestry terms have not been the subject of a separate scientific study yet, that is why the elaboration of vocabulary groups that form the core of the terminology system is promising both for the normalisation of the terminology system and for teaching students to the normative use of special names.

Scientific research in modern terminology science has led to "parallel coexistence of three main paradigmatic directions as theories recognised in the linguistic community, models of branch terminology research, agreed upon by a common trend, or three research paradigms: 1) classification-structural, taxonomic, formal; 2) functional; 3) cognitive, or discourse-cognitive, functional-cognitive" (Ivashchenko, 2014).

As Struhanets (2017) points out, "the development of the Ukrainian language word stock is a dialectically bound process of: 1) replenishment with new lexical items, 2) gradual restriction in usage, and ceasing of some nomens, which on some reasons became archaic, 3) semantic transformations, 4) stylistic transposition of the existing words". Similar processes are observed in the language of science. For this reason, systematisation of special names is necessary for studying the semantics of the term and its normalisation.

Within this framework, Cabré Castellví (2003) appropriately assumes that it is "a theory of language, which would describe and explain terminological units, should clarify how new special knowledge is produced and is synthesised in a terminological unit" (p. 191). 
Systematic structural terminology, in turn, deals with the classification and structural features of terminological units within a single terminology system (paradigm). The taxonomic paradigm acquires a special significance for our study since the taxonomy procedure (the classification of terminology units) is focused on "studying the nominative structure of the name in its projection on the designated, in the field of consciousness" (Selivanova, 2010, p. 513).

Special vocabulary of the language of science is characterised by such important features as: 1) secondary use of lexical units, developing on the basis of their original universal application; 2) special formations of artificial signs; 3) limited scope of use; 4) impossibility of direct translation into other languages; 5) impossibility of arbitrary substitutions of individual elements without the agreement with the industry's tradition; 6) a specific attitude to such linguistic phenomena as polysemy and antonymy; 7) an elevated denotative bond (Superanskaia, Podolskaia \& Vasylieva, 2005, p. 42; Pavlova, 2008).

The scholars consider all professional languages to perform two basic functions: 1) designation, naming of narrow professional specific concepts and systems of concepts (objects, signs, actions, processes); 2) specific names of well-known concepts that give them increased expressiveness and emotionality (Herd, 2005 , p. 28) in different approaches to the differentiation of various groups of terminological units forming the core of the professional language (terms, nominatives, professionalisms, slangs).

According to Prystaiko (1996), correlation in the field of scientific language with a specific (scientific, technical, industrial) concept or object can be traced in nominative units of three classes, such as terms, professionalisms and nomenclature symbols. Kyiak (2007) subdivides professional vocabulary into the following five types: "1) the terms of the given field, which have their own definitions; 2) interdisciplinary general scientific terminology units; 3) semi-terms or professionalisms, to which some researchers attribute the nomenclature, however, professionalisms, as a rule, have their own interpretations, as opposed to nomenclature units that have no definitions; 4) professional jargon that does not claim to be precise and unambiguous, though has a high level of imagery and emotionally coloured meaning; 5) commonly used words". Within any terminological system, the mentioned classes of nominative units function simultaneously, they are actively used collaterally, and they may form synonymous compounds.

The relevance of the research is due to the fact that we observe the parallel use of terms, professionalisms and common names in the speech of specialists. The clear differentiation of vocabulary groups used in the language of the particular profession will help increase the quality of the professional speech of future specialists and the level of their terminological knowledge in general. The aim of the paper is to describe the taxonomy of forestry vocabulary in the modern Ukrainian language.

\section{Material}

To carry out our research, we used the language material selected from modern terminological dictionaries, such as "Explanatory Forestry Dictionary" (Tunytsia \& Bohuslaiev, 2014), "Ukrainian Encyclopedia of Forestry" (Hensiruk, 1999, 2007), "Forestry" (Krynytskyi, 2006), "Short explanatory dictionary-reference book of terms and concepts of forestry" (Vintoniv \& Hrydzhuk, (2009). We have also interviewed forestry specialists from different regions of Ukraine.The research is based on 1050 lexical units.

\section{Methods}

The specificity of terminological material stipulated an integrated approach to the use of research methods, in particular: the study of scientific sources; the descriptive method - for registering the inventory of terms; methods of comparison(s), analysis and synthesis - for revealing the current state of this problem research, for generalisation of scientific theories; methods of classification and systematisation - for description of the taxonomy of forestry vocabulary in the modern Ukrainian language.

\section{Results and Discussion}

We may assume that forestry terminology develops according to the general language laws, therefore it will be characterised by the same groups of terminological units, the secondary use of common lexical units, the formation of special symbols, the parallel use of terms and professionalisms, etc.

As a result of the analysis of terminological material, we have revealed that taxonomy of nominative units in forestry terminology system is revealed in the functioning of four classes of nominative units, such as terms, terminologised commonly used lexical units, professionalisms and nomenclature (taxonomic) names. Let us consider each of the group in details.

1. Terms as the names of specific concepts that "must be linguistically substantiated in terms of their uniqueness, semantic transparency, sensitivity in the aspect of the correlation of national and international, and also traditional" (Kochan, 2010, p. 138). The terms "exist in the scientific language, consisting of a 
general scientific layer and a layer of special sublanguages" (Kochan, 2004, p. 17). Among the analysed forestry terminological units, we distinguish general scientific terms, interdisciplinary terms and specific terms by the degree of specialisation of their meaning.

Forestry terminology contains the following general scientific terms: aдanmauiя (adaptation), будова (structure), система (system), потенціал (potential), метод (method), вид (species), норма (norm), оптимізація (optimisation), план (plan), прогнозування (prediction), продуктивність (productivity), ресурси (resources), pid (genus), розвиток (development), структура (structure), mun (type), etc.

The vast majority of such names specify the meaning in the terminological phrase, for example: адаптація до глобальних змін клімату (adaptation to climate changse), будова деревостану (stand structure), система коренева (root system), потенціал ландшафту (landscape potential), методи обліку лісоматеріалів (methods of timber accounting), методи лісовпорядкування (methods of forest management), вид лісових культур (forest plantation species), норма рекреаційного навантаження (norm of recreational loading), оптимізаџія ландшафту (optimisation of landscape), оптимізачія екологічна (ecological optimisation), план лісонасаджень (таnagement plan area), прогнозування приростів (prediction of increments), прогнозування лісогосnодарське (forestry prediction), продуктивність деревостану (stand productivity), ресурси лісові (forest resources), система лісогосподарських заходів (system of silvicultural activities), структура лісів за віком (forest age structure), тип лісу (forest type), тип деревостану (stand type), etc.

Functioning of forestry terminology is associated with the use of the following interdisciplinary terms: biological (клімат (climate), мезорельєф (теsorelief), фітомаса (phytoтаss), флора (flora), формація (plant formation)), botanical (моноценоз (monосоепоsis), зооценоз (zоосоепоsis), породи (порода лісова (forest tree species), супутня порода (associate species)), фотосинтез (photosynthesis), фiтоклімат (phitoclimate)), zoological (зоофаги (zoоphages), орел (eagle), олень (deer), фауна лісова (forest fauna)), еcological (абіотичні фактори (abiotic factors), екосистема (есоsystem), середовище природне (natural environment), відходи (waste), ресурси (resources), екологізачія (greening)), chemical (нуклеїнові кислоти (писleic acids), фосфор (phosphorus), кальиій (calcium), сірка (sulfur)), physical (радіачійний індекс сухості (radiative dryness index), радіоактивність природна (natural radio-activity), сонячна радіачія (solar radiation), опромінення деревини (irradiation treatment of wood)), geographic (ландмарт (landscape), агроландшафти (agricultural landscapes), буферна зона (buffer zone), рельєф (relief)), есоnomic (продукиія (недеревна продукиія лісу (non-timber forest products), продукиія полювання (hunting products)), господарство (низькостовбурне господарство (соррісе system), лісонасінне господарство (seed farming)), облік (облік nтахів (inventory of birds), облік тварин (inventory of animals), облік природних ресурсів (natural resources inventory)), баланс (тепловий баланс лісу (heat balance of forest)), ревізія (revision)), medical (кругообіг (кругообіг речовин (cycle of matter), біологічний кругообіг (biological cycle)), прожилки (veins)), technical (машини (машина корувальна (debarker), машина рубильна (chipper)), трактор лісогосподарський (forestry tractor), верстат (корувальний верстат (barking machine)), технологія (technology)), architectural (мозаїка (mоsaic)), geodetic (нівелір (leveling instrument), пункт геодезичний (geodetic station)), military (планшет (plane table, map-board)).

We should note that some of these terms retain a general lexical meaning within forestry terminological system, for example: такса (fixed rate, tax) - "officially defined stable price for goods or a certain amount of payment for a particular type of labour and services" (Bilodid, 1979, p. 23) and makca (fixed rate, tax) - "cash gathering of forest harvesters in the event of the departure of the forest at the root" (Hensiruk, 2007, p. 273).

Only a small amount of terms shows the narrowing of their meaning (compare: таксаиiя (inventory) "1. Definition of a tax, prices for anything... 2. Material assessment of the forest (determination of the stock and quality of wood, growth, volume of timber, etc.). 3. Determining the quantity and quality of something" (Bilodid, 1979, p. 24) and таксаиія лісосік (valuation of harvest area) - "the determination of the stock, the output of intermediate assortments and the tax cost of wood in the stands" (Hensiruk, 2007, p. 274), таксаиія лісу вибіркова (variable plot sampling) - "identification of quantitative and qualitative characteristics of the entire forest object" (Hensiruk, 2007, p. 275); acouiauiя (association) - "1. Voluntary association of individuals or organisations for achieving a common economic, political, and cultural goal; partnership, union. 2. Connection of something in a whole. 3. Relationship between individual neuropsychological acts..." (Busel, 2005, p. 43) and асоиіація (association) - "naturally formed within a certain range with similar conditions of existence, vegetation, homogeneous in species composition..." (Tunytsia \& Bohuslaiev, 2014, p. 24)).

We can fix the change of the value of a small number of terms within the forestry terminological system (compare: абрис (outline) - "1. Outline of the subject; contour... // Contour drawing. 2. General characteristics of the phenomena, persons, review of events, etc." (Bilodid, 1970, p. 5) and aбpuc (outline) - "hand-made 
schematic plan of the land plot with the designation of contours of land, local objects, measurement results on it..." (Hensiruk, 1999, p. 14); актуалізація (updating) - "regular changes to information funds...; a set of operations to maintain an information base in a state that reflects all changes to the object at the current time" (Busel, 2005, p. 19) and актуалізаиія (updating) - "bringing the forest fund data of different prescription to one date; one of the comparative-historical methods of studying the history of forest development" (Hensiruk, 1999, p. 23); maкcamop (cruiser) - "1. Taxation specialist. 2. Tax agent" (Busel, 2005, p. 1428) and таксатор (cruiser) - "forestry specialist, forestry engineer, who performs the entire complex of field and office logging operations" (Tunytsia \& Bohuslaiev, 2014, p. 363)).

The pure forestry terms form the core of the analysed terminology and designate the names of the industry specialists (лісозаготівельник (feller), лісовпорядник (timber appraiser), лісничий (forester), лісівник (forest ranger), лісник (woodward), єгер (gamekeeper), лісоруб (feller)), forest science (лісова таксаиія (forest inventory), лісознавство (forest science), деревинознавство (wood science), лісівництво (forestry), лісова типологія (forest typology), лісова пірологія (forest fire science), лісова екологія (forest есоlogy)), forest land signs (лісостан (forest stand), лісове насадження (forest plantation), деревостан (stand), середнньовіковий деревостан (middle age stand), зімкнений деревостан (closed stand)), groups of tree species (порода деревна панівна (dominant species), супутня порода (associated species), порода з високою щільністю деревини (highdensity wood), тіньовитривалі породи (shade tolerant species), сонцелюбні породи (shade intolerant species)), types of forest litter (муль (mild huтиs, mull), модер (moder), мор (mor)), processes (лісорозведення (afforestation), заліснення (forestation), лісосічні роботи (cutting area operations), добровільно-вибіркова рубка (selection felling), рівномірно-поступова рубка (uniform shelterwood felling), суиільна рубка (clea felling), санітарна рубка (sanitation felling), корчування пеньків (stump extraction), трелювання (skidding)), machinery, equipment (машина корувальна (debarker), машина звалювально-гілкорізна (feller-delimber), машина трелювальна із захоплювачем (grapple skidder), сортиментовоз (forwarder), машина гілкорізна (delimber)), etc.

2. Terminologised common lexical units form a significant group in the terminological system of forestry. Such terms are understandable to an average native speaker, who actively uses them in his/her speech. However, these lexemes are an obligatory component of the terminological system, since without them its integrity will be broken. The use of spoken words to denote the names of specific concepts are the basis of this process, as either broadening or narrowing of their meaning occurs most frequently. "Movement from the sphere of common vocabulary to the terminology takes place in two directions: through the development of secondary terminological meanings in general lexical units and by the use of commonly used words in complex terms" (Struhanets, 2001, p. 256).

Styshov (1999) considers the reasons for the semantic development of words. They are "logical and psychological factors (the peculiarities of associative thinking, peculiarity of each ethnic group mentality, the influence of the individual-author's worldview, thinking and linguistics of a widely spoken language, etc.), as well as factors of socio-historical character, the social value of certain realities and concepts in certain periods of social development, and the corresponding discovery of this actualisation in thematic groups of the vocabulary, etc." (p. 13). Common names were originally used in oral professional speech, subsequently they were applied to specific concepts in scientific publications, and as a result, such names were fixed as common scientific terms.

Within the forestry terminological system, such processes refer to the names of forest areas (галявина (glade), гущавина (thicket), криволісся (scrub forest), узлісся (edge of a forest), урочище (isolated terrain feature), перелісок (field wood-land), підлісок (undergrowth)), forest types (березняки (birch forests), букняки (beech forests), вільшняки (alder forests), грабняки (hornbeam forests), діброва (oak forest), tree species (молодняк (young growth), жердняк (pole-stage forest), підгін (accessory species)), parts of the tree (вершина (tree-top), гілка (branch), дупло (риор), корінь (root), листок (sheet)), wood defects (зарість (wood damage), завиток (wood wawe), пасинок (side-shoot), прожилки (veins), тріщини (cracks), червоточина (worm holes)), plant names (береза (birch), вільха (alder), конвалія (lily of the valley), ромашка (camomile), дуб (oak), сосна (pine), ялина (spruce)), birds (лелека (stork), ластівка (swallow), перепілка (quail), сова (owl)), animals (вовк (wolf), лисиия (fox), ведмідь (bear)), process names (обкорування (peeling), освітлення (first cleaning), підпил (undercut), проріджування (thinning), проростання (germination)), plant diseases (рак (canker), опік (scorch)), etc.

The distinctive feature of some forestry terms is the identity of their meaning with the meaning of a common word. For example, such lexemes as дерево (tree), діброва (oak forest), калина (viburnит), клен (maple), nidmena (rootstock), nidpicm (undergrowth), суховерхість (stagheadedness), жердняк (polestage forest), деревостан (forest stand), ярусність (storeyed structure) are recorded in the Dictionary of the Ukrainian Language as common words, for example: “ДЕРЕВО (tree). 1. Perennial plant with a solid trunk 
and branches forming a crown. 2. Wood of this plant, going to construction and various products" (Bilodid, 1971, p. 246); “ДІБРОВА (oak forest). Deciduous forest on the fertile soils where oak prevails" (Bilodid, 1971, p. 296); “КАЛИНА (viburnum). 1. Shrubby plant... 2. The berries of this plant” (Bilodid, 1973, p. 76); "ПІДШЕПА (rootstock). The plant to which the shoot or bud of another plant is replanted" (Bilodid, 1975, p. 526); "ПІДРІСТ (undergrowth). Group of young trees of the main species in any forest" (Bilodid 1975: 492); "ЯРУСНІСТЬ (storeyed structure). The location of something in rows, tiers" (Busel, 2005, p. 1649); "СУХOВЕРХІСТЬ (stagheadedness). Drying of the tops of trees" (Busel, 2005, p. 1418); "ДЕРЕВОСТАН (forest stand). It is the same as a tree stand" (Bilodid, 1971, p. 246).

Some special dictionaries provide the mentioned lexemes as terms: дерево (tree) - "perennial plant with a distinctive above ground trunk, crown and roots" (Tunytsia \& Bohuslaiev, 2014, p. 99), діброви (оak forests) - "forest ecosystems with domination in the rootstock of one of oak species" (Hensiruk, 1999, p. 219), nidmena (rootstock) - "a plant to which the shoot or bud of another plant is replanted" (Hensiruk, 2007, p. 135), калина (viburnum) - "the genus of the bush family of honeysuckle" (Hensiruk, 1999, p. 326), nidpicm (undergrowth) - "a young generation of woody plants under the canopy of a forest or on felled areas" (Vintoniv \& Hrydzhuk, 2009, p. 55), ярусність (storeyed structure) - "vertical subdivision of the tree stand on the storeys" (Krynytskyi, 2006, p. 73), суховерхість (stagheadedness) - "dying of tops and upper branches of the crown of a tree" (Krynytskyi, 2006, p. 67), деревостан (forest stand) - "a group of trees forming more or less homogeneous forest area" (Vintoniv \& Hrydzhuk, 2009, p. 24).

Common words can often specify the meaning, gaining signs of the term, thus ensuring the requirement for unambiguous terms, compare, for example: підгін (accessory species) - "1. Action meaning підганяти. 2. A shrubby, wood species planted for the accelerated growth of slowly growing species. 3. An additional sprout of the cereals that is formed later from the main stem" (Bilodid, 1975, pp. 413-414) and nidziн (accessory species) - "in forestry, it is secondary tree species creating with the participation of favourable conditions for the growth of the main tree species" (Hensiruk, 2007, p. 132); насінник (seed tree) - "1. A plant, a fruit of the plant, as well as the grains, tubers left as seeds. 2. A plot intended for growing plants for seeds together with these plants. 3. Seed specialist" (Bilodid, 1974, p. 188) and насінники (sеed tree) "trees that remain at the root during clear cutting of the forest for subsequent sowing of the log for natural renewal" (Hensiruk, 2007, p. 56); освітлення (first cleaning) - "1. Action meaning освітлити. 2. The light from any source. 3. Technical equipment that is a source of light" (Bilodid, 1974, p. 755) and освітлення (first cleaning) - "tending young under 10-year old growth, held in all plantations" (Hensiruk, 2007, p. 101).

Generally used lexical units are also used as components of terminological word combinations, for example: напрям (напрямок лісосіки (felling area direction), напрям рубань (direction of cutting operation)), насіннєвий (насіннєвий контроль (seed kontrol), насіннєвий матеріал (seed stock)), ліс (стиглість лісу (forest exploitability), намет лісу (forest canory), ліси рекреаційні (recreational forests), ліси острівні (forest outliers)), вік (вік лісових культур (forest plantation age), вік деревостану (stand age), вік рубок (cutting age)), дубовий (дубовий ліс (oak forest), дубовий похідний шовкопряд (processionary moth), листовійка зелена дубова (green oak roller moth), дубова чубатка (oak puss moth), дубовий блошак (oak flea beetle), златка бронзова дубова (bronze oak borer), заболонник дубовий (oakbark beetle), короїд дубовий непарний (european shot-hole borer)) etc.

3. Professionalism is a word or phrase inherent in the language of a particular professional group. Such names are used "as spoken synonyms-equivalents to the stylistically individual professional nomenclature or words-terms, and often beyond the limits of the literary norm" (Rusanivskyi \& Taranenko, 2004, p. 537).

The use of professionalisms is conditioned by the specifics of the specialists' activities in the field of forestry and is associated with the use of a significant number of dialectal names in the analysed terminological system.

In the field of forestry professionalisms are nationally specific realities. Some of them do not have English equivalents and some of them are dialect names. Forestry professionalisms serve to denote the names of individuals according to the type of activity (гаєвий (haievyi) / гайовий (haiovyi) = a forest guard), types of weapon (горизонталка (horyzontalka) = a smooth-bore rifle with horizontal placement of trunks, двостволка (dvostvolka) = a smooth-bore rifle with two trunks, трійник (triinyk) = combined rifle with smooth-bore and threaded trunks, umyuep (shtutser) = single-shot rifle carbine, болтовик (boltovyk) $=$ threaded carbin with hand reloading of bangs, бок (bok) $=$ a smooth-bore rifle with vertical placement of trunks), production facilities in the forest (верхній склад (verkhnii sklad) = forest log depot, нижній склад (nyzhnii sklad) = industrial log depot, волок (volok) = skidding road, естакада (estakada) = landing, шкілка $($ shkilka $)=$ nursery, маточник (matochnyk) = forest seed orchard), types of plantation (матки $($ matky $)=$ elite trees, cymкa $($ sushka $)=$ snag), density of plantation and crown $($ wyбa $($ shuba $)=$ a group of trees or bushes that contribute to the formation of a better microclimate for the main species at a young age 
by uniformly scattered shading, вікна (vikna) = gaps between the crowns of the trees, дуб в шубі (dub $v$ shubi) = lighting of the top of the oak seedlings), plantation storey (ранжир (ranzhyr) = tree layer), parts of wood and its defects (смільняк (smilniak) = resin stump, обрізки (obrizky) = wood waste, рогівка (rohivka) $=$ hardened wood, pозчаx (rozchakh) = crack in the wood along the trunk), way of cutting knots (за nidлище (za pidlytse) = cutting knots to the level with the surface of the log), tools (клюna (kliupa) = calipers, ланиет (lantset) = Kolesov's sword, вісняк (visniak) = a cutting instrument for bark removing, ромпак $($ rompak) $=$ cutter), various kinds of processes (штабелювання лісу (shtabeliuvannia lisu) = stacking of roundwood, штамповка (shtampovka) = marking of trees, приделовка (prydelovka) = grafting of seedlings, niдсочка (pidsochka) $=$ the process of extraction birch or maple sap), beetles (друкар (drukar) = eighttoothed engraver beetle, садівник (sadivnyk) = lesser pine-shoot beetle), animals (косий (kosyi) = rabbit, рогач $($ rohach $)=e l k$, coхатий $($ sokhatyi $)=e l k$, ciкач $($ sikach $)=$ wild boar, cipaк $($ sirak $)=$ wolf), layers of wood (літовище (litovyshche) = a layer of wood, which determines the tree age, нізка (nizka) = a layer in a tree, located directly under the bark) etc.

Such names "leave an opportunity for users, who are interested in the development of Ukrainian technical knowledge, to experiment and improve terminology on our own language foundations, introduce new equivalents more boldly, look for intelligent dialectics between the borrowed and our own" (Doroshenko, Lysenko \& Tievikova, 2018).

Summarising the problem of the correlation between terminology and professional vocabulary, Pavlova (2008) singles out three opinions. According to the first opinion, these two concepts are identical. The second opinion indicates the difference between professional vocabulary and terminology due to a certain historical feature. The third opinion suggests that terms and professionalisms have both common and distinctive features. Pavlova (2008) focuses on the attributes that help distinguish between professionalisms and terms. We submitted them in the Table 1.

Table 1. Distinctive features of terms and professionalisms

\begin{tabular}{|c|c|}
\hline Professionalisms & Terms \\
\hline $\begin{array}{l}\text { Do not belong to the normative special } \\
\text { vocabulary. }\end{array}$ & $\begin{array}{l}\text { Are the normative part of the special vocabulary of the } \\
\text { scientific language. }\end{array}$ \\
\hline $\begin{array}{l}\text { Are rarer in general and special dictionaries, } \\
\text { they exist mainly in the field of functioning. }\end{array}$ & $\begin{array}{l}\text { Are fixed in dictionaries and function simultaneously } \\
\text { in two areas (fixation and functioning). }\end{array}$ \\
\hline $\begin{array}{l}\text { Are used predominantly in oral, or spoken } \\
\text { language. }\end{array}$ & Written speech is the dominant sphere of functioning. \\
\hline Have a somewhat broader scope of special use. & $\begin{array}{c}\text { May be known to people not related to the outlined } \\
\text { professional field. }\end{array}$ \\
\hline $\begin{array}{l}\text { Are characterised by striving for } \\
\text { expressiveness, imagery, expression. }\end{array}$ & Are devoid of connotation, i.e. expressive colouring. \\
\hline $\begin{array}{l}\text { Systemic connections are less pronounced } \\
\text { within the framework of a particular field. }\end{array}$ & $\begin{array}{l}\text { Systemic connections are expressed to a large extent } \\
\text { within the framework of a particular field. }\end{array}$ \\
\hline $\begin{array}{l}\text { Appear during professional communication as } \\
\text { secondary forms of expression and are used } \\
\text { frequently as professional-colloquial doublets of } \\
\text { official terms. }\end{array}$ & $\begin{array}{l}\text { Appear in the process of scientific research and } \\
\text { function in scientific communication. }\end{array}$ \\
\hline $\begin{array}{l}\text { Are characterised by a lower degree of } \\
\text { specialisation of word-formation means } \\
\text { comparing to the terms. }\end{array}$ & $\begin{array}{l}\text { Are characterised by a higher degree of specialisation } \\
\text { of word-formation means. }\end{array}$ \\
\hline $\begin{array}{c}\text { Belong to the periphery of the terminological } \\
\text { system. }\end{array}$ & Belong to the centre of the terminological system. \\
\hline
\end{tabular}

The distinctive features provided in Table 1 are typical of forestry professionalisms as well. We will try to describe them more specifically.

Firstly, forestry professionalisms do not belong to the normative special vocabulary, they are used mainly in oral communication, and spoken language, since, as mentioned above, they have parallel dialect names (for example, тис (yew) - тіс (tis), тес (tеs), тесина (tеsуnа), негній-дерево (nеhniі-dегеvo); ясен (ash) - ясінь (yasin'), елем (elem), падуб (раdиb), ясенина (yasenyna), ясень (yasen')). Therefore, such names are not recorded in special dictionaries.

Secondly, these terms are used in professional communication as doublets of official terms (for 
example, бок (bok), вертикалка (vertykalka) = a smooth-bore rifle with vertical placement of trunks; шкілка (shkilka) = розсадник (nursery)).

Thirdly, they have a low degree of specialisation of word-formation means comparing to the terms (when analysing professionalisms, we found only one suffix -k-, which was used to form the names of different types of rifles (for example, вертикалка (vertykalka) = a smooth-bore rifle with vertical placement of trunks, горизонталка (horyzontalka) = a smooth-bore rifle with horizontal placement of trunks, одностволка (odnostvolka) $=$ a smooth-bore rifle with one trunk).

Fourthly, they have figurative, expressive colouring (for example, бородa (boroda) $=$ a sharp increase in the diameter at the bottom of the trunk, вовчки (vovchky) = strong, upwardly directed shoots developing from dormant buds on trunks and large branches of trees, дуб в шубi (dub v shubi) = lighting of the top of the oak seedlings, хлист (khlyst) = tree trunk).

The analysis performed confirms the arguments of Lahodynskyi, Mamchur and Skab (2018) that such "lexical units can be placed under the category of 'professionalisms' because they do not meet the 'terminology' requirements in full scope, in terms of preciseness of their definitions; changeability of meaning depending on the context as well as stylistic markings" (p. 183).

4. Nomenclature is a set of names used in any branch of science and production to designate objects in this industry, in contrast to the terminology that combines the names of abstract concepts and categories (Yermolenko, Bybyk \& Todor, 2001, p. 106). Vinokur (1939) asserts that "unlike terminology, nomenclature is to be understood as a system of completely abstract and conditional symbols, the only purpose of which is to provide the most convenient, from a practical point of view, means for the determination of objects, things, without any direct correlation to the needs of theoretical thought that operates these things". Pavlova (2008) interprets "symbolic, conditional names of verbal or digital structure, specially created on the basis of terms of a denotative type", as nomenclature denotations. Komarova (1991) defines the main features of the nomens: 1) agreement with the concepts through the term; 2) belonging to the proper names or an intermediate position between terms and proper names; 3 ) belonging to the simplest system, that represents a list of homogeneous concepts or objects that are on the same level of abstraction; 4) functioning of the special vocabulary as a lower link, since it is impossible to understand such names without comparing with other terminological units.

Nomenclature names in the analysed forestry terminological system have their own peculiarities of use, in particular, the names applied to designate the following:

- wood species (Ялє (ялина європейська (Picea abies L.)), Яиб (ялиия біла (Abies alba Mill.)), Сз (сосна звичайна (Pinus sylvestris L.)), Мдє (модрина європейська (Larix decidua Mill.)), Дз (дуб звичайний (Quercus robur L.)), Дс (дуб скельний (Quercus petraea Liebl.)), Дчр (дуб червоний (Quеrcus rubra Du Rei)), Бкл (бук лісовий (Fagus sylvatica L.)), Клг (клен гостролистий (Acer platanoides L.)), Яв (клен-явір (Acer pseudoplatanus)), Гз (граб звичайний (Carpinus betulus L.)), Бб (береза бородавчаста (Betula verrucosa Ehrh.)), Бn (береза пухнаста (Betula pubescens Ehrh.)), Лпд (липа дрібнолиста (Tilia cordata Mill.)),Влч (вільха чорна (Alnus glutinosa L.)), Влс (вільха сіра (Alnus incana L.));

- types of tree felling (рубки Ебергарда (Ebergard felling), рубки Kаутия (Kauts felling), рубки Корнаковського (Kornakovsky felling), рубки Кравчинського (Kravchynsky felling));

- means of direct extinguishing of forest fires (агрегат лісопожежний (forest fire-control unit) (АЛП-10 (АLP-10), ТЛП-55(ТLP-55)), мотопомпи лісові пожарні (тоtor fire ритрs) (MЛВ-1 (MLV-1), ПМП-1Л (РМР-1L), МЛ-100 (ML-100), МП-800(МР-800)), торф'яний ствол (реat tube) (TC-1M (TS$1 M)$ ), запалювальний пристрій (device used for setting fire) (3A-ФK (ZA-FK), 3A-ФKT (ZA-FKT)).

Latin names of the flora and fauna, used collaterally with specific terms, are also considered as nomenclatural units. Their use enables the communicative interaction with representatives of forestry professions from other countries, such as botanical names (Vaccinium myrtyllus L. (чорниия), Capsella bursa pastoris L. (грицики звичайнi), Majantemuт bifolium L. (веснівка дволиста), Triticum vulgare (пшениия звичайна), Linum иsitatissimuт (льон звичайний) Berberis L. (барбарис звичайний)) and zoological names (Urcus arctos (ведмідь бурий), Martes martes (куниия звичайна), Lynx lynx (рись звичайна), Coturnix coturnix (перепілка звичайна), Phasianus colchicum (фазан звичайний), Astacus astacus (рак річковий), etc.).

These are preferably two- and three-component compounds, in which the signifying component specifies an attribute, for example: дятел звичайний / білоспинний / малий / сирійський / середній (Dendrocopos major / leucotos / minor / syriacus / medius), заєць білий / сірий (Lepus timidus / europaeus), олень благородний / плямистий / біломордий (Cеrvus elaphus / nippon / albirostris), бобер європейський / канадський (Castor fiber / canadensis)).

The taxonomic names used in forestry terminology also belong to the nomenclature. We will illustrate 
the rules of such nomens formation on the example of taxonomic names of woody plants. By structural features they are mainly two-, and less frequently three-component terminological phrases (біота східна золотава (Biota orientalis Endl.), водяний жовтеиь (Bartachium), вовче лико кавказьке (Daphnе caucasica)) with an obligatory specifying component - adjective (абелія корейська (Abelia согеапа), глід м'який (Crataegus submollis), ялина звичайна (Picea abies L.)), the participle (атрус відхилений (Grossularia reclinata (L.)), пирій повзучий (Elytrigia repens (L.)), елеутерокок колючий (Eleutherococcus senticosus Maxim.), глід згладжений (Crataegus laevigata (Poir.))), and noun (барбарис Жиральда (Berberis giraldi Hesse), тополя Симона (Рорulus simonii), калина Карльса (Viburnum carlesii Hemsl.), береза Шмідта (Betula schmidtii)).

The attributive component in taxonomic names most frequently indicates the following characteristics:

- the shape or size of a stem, flower, fruit or leaf (барбарис коротконіжковий (Berberis branchypoda), барбарис дрібнолистий (Berberis parvifolia), бузина широколисточкова (Sатbисиs latipinna Nakai), глід сливолистий (Crataegus), магнолія зірчаста (Magnolia stellata), птелея трилиста (Ptelea trifoliata L.), платан кленолистий (Platanus acerifolia));

- origin (мандарин японський (Citrus unshiu Marc.), бузок угорський (Syringa josikaea Jacq.), бузок перський (Syringa persica L.), смородина альпійська (Ribes alpinum L.), модрина сибірська (Larix sibirica Ledeb.), модрина японська (Larix leptolepis Cord.), суниия чилійська (Fragaria chiloensis L.), лимонник китайський (Schisandra sinensis Bail.), верба лапландська (Salix lapponuт L.));

- colour (смородина золотиста (Ribes aureum Pursh.), смородина червона (Ribes rubrum L.), бузина чорна (Sambucus nigra L.), верба біла (Salix alba L.), вільха сіра (Alnus incana L.), дуб двоколірний (Quercus bilokor Wild.), жимолость голуба (Lonicera caerulea L.), клен сріблястий (Acеr dasycarpum Ehrh.), ломиніс фіолетовий (Cleтаtis viticella L.), півонія жовта (Paеопia lutea Franch));

- surname of the researcher (береза Максимовича (Betula maximowiczii Regel), бузок Вольфа (Syringa wolfii C.K. Schneid), калина Biчa (Viburnum veitchii C.H. Wright), магнолія Ватсона (Magnolia watsonii Hook.), сосна Культера (Pinus coulteri D. Don), тополя Вільсона (Рориlus wilsonii Schneid), очиток Pупрехта (Sedum ruprechtii (Jalas) Omelcz.), черемха Грея (Padus grayana Maxim.), иипшина Бегzера (Rosa beggeriana Schrenk), липа Wnema (Tilia spaethii Spaeth));

- zoonotic sign (ліщина ведмежа (Corylus colurna), шипшина собача (Rosa canina L.), вишня пташина (Cerasus avium (L.) Moench), виноград лисячий (Vitis vulpina), зозулині черевички справжні (Cypripedium calceolus L.), гірчак змї̈ний (Polygonum bistorta L.), верба козяча (Salix caprea L.));

- personal sign (ялівець козацький (Juniperus coтmипіs L.), дівочий виноград n'ятилисточковий (Parthenocissus quinquefolia (L.) Planch));

- forest conditions (бук лісовий (Fagus sylvatica L.), виноград прибережний (Vitis riparia Michx.), виноград скельний (Vitis rupestris Scheele), журавлина болотна (Oxусоссиs palustris Pers.), вишня чагарникова (Cerasus fruticose (Pall.) G.Woron), дуб скельний (Quercus petraea (Mattuschka) Liebl.), мигдаль степовий (Amygdalus nana L.), яблуня лісова (Malus sylvestris (L.) Mill.), сосна гірська (Pinиs montana), горобина домашня (Sorbus domestica L.), гравілат річковий (Geum rivale L.));

- function (берека лікувальна (Sorbus torminalis (L.) Crantz.), жасмин лікарський (Jаsтіпит officinale L.));

- flowering period (барбарис весняний (Berberis vernae Schneid.), вейгела рання (Weigela praecox (Lemoine) Bailey), гамамеліс весняний (Hamamelis vernalis Sarg.), иипшина травнева (Rosa majalis Herm.), черемха пізня (Padus serotine (Ehrh.) Agargh.));

- expressive signs (тополя могутня (Рopulus robusta Schneid.), туя велетенська золотавостроката (Thuja plicata 'Aureo-variegata'), туя західна елегантна (Thuja occidentalis 'Elegantissima'), ялиия благородна (Abies nobilis Lindl.), золотий дощ звичайний (Laburnum anagyroides Medic.), дейџія найелегнтніша (Deutzia elegantissima (Lemoine) Rehd.), дейція гращуіозна (Deutzia gracilis Sieb. et Zucc.));

- other visual or tactile signs (береза пухнаста (Betula pubescens Ehrh.), верба ламка (Salix fragilis L.), слива розлога (Prunus divaricate Ledeb.), фотінія ворсиста (Photinia vilosa (Thunb.) DC.), приворотень стрункий (Alchemilla gracilis Opis), яблуня рясноивіта (Malus floribunda Sieb.), робінія клейка (Robinia viscosa), сосна гнучка (Pinus flexilis), ожина шорстка (Rubus hirtus Waldst.)).

The adjective звичайний (ordinary) is the most typical component of taxonomic names (болотний кипарис звичайний (bald cypress), підбіл звичайний (Tussilago farfara L.), підсніжник звичайний (Galanthus nivalis L.), вишня звичайна (Cerasus vulgaris Mill.), печіночниця звичайна (Hepatica nobilis Mill.), калина звичайна (Viburnuт ориlus), горобина звичайна (Sorbus aисирагіa L.) etc).

Summarising the analysis of taxonomic names, we can see that the attributive component in term phrase specifies the semantics of the core word defining its differential characteristics. 


\section{Conclusions}

The development of industry terminological systems is relevant in Ukrainian linguistics. Having analysed a number of forestry terms based on modern terminology glossaries, we may conclude that the same groups of special names are inherent for the analysed terminology as well as other terminological systems. Consequently, we have obtained the following groups: general scientific terms; inter-disciplinary terms; special terms; terminologised commonly used lexical units; professionalisms; nomenclature nominations. We can also conclude that described groups of terms are used simultaneously in the language for specific purposes.

Our survey has shown that certain semantic processes can be distinguished in the analysed terminological system. They are as follows:

1. The retaining of a general lexical meaning of the term within the forestry terminological system.

2. The narrowing of term meaning.

3. The change of term value within the forestry terminological system.

Terminologised lexical units also specify their meaning being a part of terminological word combinations.

The peculiarity of the forestry terminological system is that it actively employs terminologised lexical units. Such terms denote the names of the plant, birds, animals, forest areas, forest types, tree species, parts of the tree, wood defects, process names, etc. The fact that flora and fauna are also the objects of forestry determines the necessity to use nomenclature names in the forestry terminological system.

The process of professional communication implies knowledge of special terminology. The task of Forestry University is both training of specialists for the forestry sector and the specialists focused on the scientific activity. Their mastery of the language of the profession also means considerable proficiency in special terminology, primarily, in the theoretical aspect as well as the development of their system of language and terminology knowledge highlighted in the article.

The presented theoretical analysis of forestry terminology will become the basis for practical classes and will promote the enhancement of motivation of students in forestry specialities in order to succeed in learning. This theoretical analysis will be used in future didactic research as well.

\section{References:}

Bilodid, I. (Ed.). (1970). Slovnyk ukrainskoi movy (T.1) [Dictionary of the Ukrainian language (Vol.1)]. Kyiv, Ukraine: Naukova dumka. Bilodid, I. (Ed.). (1971). Slovnyk ukrainskoi movy (T.2) [Dictionary of the Ukrainian language (Vol.2)]. Kyiv, Ukraine: Naukova dumka. Bilodid, I. (Ed.). (1973). Slovnyk ukrainskoi movy (T.4) [Dictionary of the Ukrainian language (Vol.4)]. Kyiv, Ukraine: Naukova dumka. Bilodid, I. (Ed.). (1974). Slovnyk ukrainskoi movy (T.5) [Dictionary of the Ukrainian language (Vol.5)]. Kyiv, Ukraine: Naukova dumka. Bilodid, I. (Ed.). (1975). Slovnyk ukrainskoi movy (T.6) [Dictionary of the Ukrainian language (Vol.6)]. Kyiv, Ukraine: Naukova dumka. Bilodid, I. (Ed.). (1979). Slovnyk ukrainskoi movy (T.10) [Dictionary of the Ukrainian language (Vol.10)]. Kyiv, Ukraine: Naukova dumka.

Busel, V. (Ed.). (2005). Velykyi tlumachnyi slovnyk suchasnoi ukrainskoi movy [Great explanatory dictionary of modern Ukrainian language]. Kyiv, Irpin, Ukraine: VTF "Perun".

Cabré Castellví, M. T. (2003). Theories of terminology: their description, prescription and explanation. Terminology. International Journal of Theoretical and Applied Issues in Specialized Communication, $9(2), \quad 163-199$. https://doi.org/10.1075/term.9.2.03cab

Doroshenko, S., Lysenko, A., \& Tievikova, O. (2018). Ukrainian scientific and technical terminology formation and development peculiarities. International Journal of Engineering and Technology (UAE), 7 (3), 539-544. Retrieved from https://www.sciencepubco.com/index.php/ijet/article/view/14585

Gerd, A. (2005) Prikladnaya lingvistika [Applied Linguistics]. Sankt-Peterburg, Russia: Izd-vo S.-Peterb. un-ta.

Hensiruk, S. (Ed.). (1999). Ukrainska entsyklopediia lisivnytstva (T.1) [Ukrainian Encyclopedia of Forestry (Vol.1)]. Lviv, Ukraine: NVF "Ukrainski tekhnolohii”.

Hensiruk, S. (Ed.). (2007). Ukrainska entsyklopediia lisivnytstva (T.2) [Ukrainian Encyclopedia of Forestry (Vol.2)]. Lviv, Ukraine: NVF "Ukrainski tekhnolohii".

Ivashchenko, V. (2014). Osnovni napriamy doslidzhen u terminoznavstvi kintsia XX - pochatku XXI stolit [The main directions of researches in the terminology of the late XX - early XXI centuries]. Visnyk Nats. un-tu "Lvivska politekhnika". Seriia "Problemy ukrainskoi terminolohii", 791, 22-26.

Kyiak, T. (2007). Apolohiia linhvistyky fakhovykh mov [Apology of linguistics of professional languages]. Ukrainska terminolohiia i suchasnist, VII, Kyiv, 18-21.

Komarova, Z. (1991). Semanticheskaya struktura spetsialnogo slova i ee leksikograficheskoe opisanie [Semantic structure of a special word and its lexicographical description]. Sverdlovsk, Russia: Izd-vo Uralskogo un-ta.

Kochan, I. (2004). Dynamika i kodyfikatsiia terminiv z mizhnarodnymy komponentamy v suchasnii ukrainskii movi [Dynamics and codification of terms with international components in modern Ukrainian language]. Lviv, Ukraine: Vydavnychyi tsentr LNU imeni Ivana Franka.

Kochan, I. (2010). Movna norma i termin [Language norm and term]. Doslidzhennia z leksykolohii i hramatyky ukrainskoi movy, 9 , 138-149.

Krynytskyi, H. (Ed.). (2006). Lisivnytstvo: terminolohichnyi slovnyk [Forestry: a terminology dictionary]. Lviv, Ukraine.

Lahodynskyi, O., Mamchur, K., \& Skab, V. (2018). English spycraft professionalisms as a linguistic phenomenon. Advanced Education, 9, 178-184. https://doi.org/10.20535/2410-8286.121575

Lotte, D. (1961). Osnovy postroyeniya nauchno-tekhnicheskoy terminologii. Voprosy teorii i metodiki [Bases of scientific and 
technical terminology construction. Questions of theory and methodology]. Moscow, Russia: Izd-vo AN SSSR.

Pavlova, O. (2008). Terminy, profesionalizmy i nomenklaturni znaky (do problemy klasyfikatsii spetsialnoi leksyky) [Terms, professionalism and nomenclature signs (to the problem of the classification of special vocabulary)]. Visnyk Nats. universytetu "Lvivska politekhnika". Seriia "Problemy ukrainskoi terminolohii", 620, 49-54.

Pristayko, T. (1996). Leksiko-nominativnaya organizatsiya spetsialnogo teksta [Lexical and nominative organization of the special text]. Dnepropetrovsk, Ukraine:UkO IMA-pres.

Selivanova, O. (2010). Linhvistychna entsyklopediia [Linguistic Encyclopedia]. Poltava, Ukraine: Dovkillia-K.

Styshov, O. (1999). Osoblyvosti rozvytku leksychnoho skladu ukrainskoi movy kintsia XX st. [Features of the development of the lexical composition of the Ukrainian language at the end of the XX century]. Movoznavstvo, 1, 7-21.

Struhanets, L. (2001). Terminolohizatsiia leksychnykh odynyts suchasnoi ukrainskoi literaturnoi movy [Terminologisation of lexical units of modern Ukrainian literary language]. Nauka i suchasnist, XXVI, 255-268.

Struhanets, L. (2017). Development of the Ukrainian language word stock of the 20th - beginning of the 21st centuries. Analele Universităţii din Craiova. Seria Ştiinţe Filologice. Lingvistică, XXXIX, 1-2, 409-414. EAN13: 12245712.

Superanskaya, A., Podolskaya, N., \& Vasileva, N. (2005). Obschaya terminologiya: Terminologicheskaya deyatelnost [General terminology: terminological activity]. Moscow, Russia: URSS Editorial.

Tunytsia, Yu., \& Bohuslaiev, V. (Eds.). (2014). Lisotekhnichnyi terminolohichnyi slovnyk: ukrainskyi, rosiiskyi, anhliiskyi [Explanatory Forestry Dictionary: Ukrainian, Russian, English]. Lviv, Ukraine: Piramida.

Rusanivskyi, V., \& Taranenko, O. (Eds.). (2004). Ukrainska mova: entsyklopediia [Ukrainian language: encyclopedia ]. Kyiv, Ukraine: Ukrainska entsyklopediia.

Vinokur, G. (1939). O nekotorykh yavleniyakh slovoobrazovaniya v russkoy tekhnicheskoy terminologii [On some phenomena of word formation in Russian technical terminology]. Trudy Mosk. in-ta istorii, filosofii i lit.: sbornik statey po yazykoznaniyu, $5,3-54$.

Vintoniv, R., \& Hrydzhuk O. (Eds.). (2009). Korotkyi tlumachnyi slovnyk-dovidnyk poniat i terminiv lisivnytstva [Short explanatory dictionary-reference book of terms and concepts of forestry]. Lviv, Ukraine: NLTU Ukrainy.

Yermolenko, S., Bybyk, S., \& Todor, O. (2001). Ukrainska mova: Korotkyi tlumachnyi slovnyk linhvistychnykh terminiv [Ukrainian language: Short explanatory dictionary of linguistic terms]. Kyiv, Ukraine: Lybid.

Received: March 27, 2018

Accepted: May 06, 2019 